Hodge, S. M. 1978: USGS Mono-pulse ice radar. U.S. geol. Surv. Open File Rep. 9 pp.

Olesen, O. B. \& Clausen, A. 1988: Test drilling with a hot water jet at the Inland Ice margin, Pâkitsup, central West Greenland. Rapp. Grønlands geol. Unders. 140.

Thomsen, H. H. 1988: Mapping and modelling of glacier drainage in the. Pâkitsoq basin, central West Greenland. Rapp. Grønlands geol. Unders. 140.

Thorning, L., Thomsen, H. H. \& Hansen, E. 1986: Geophysical investigations over the Inland Ice margin of the Pâkitsoq basin, central West Greenland. Rapp. Grønlands geol. Unders. 130, 114-121.

Thorning, L. \& Hansen, E. 1987: Electromagnetic reflection survey 1986 at the Inland Ice margin of the Pâkitsoq basin, central West Greenland. Rapp. Grønlands geol. Unders. 135, 87-95.

Thorning, L. \& Hansen, E. 1988: Electromagnetic reflection survey 1987 in key areas of the Pâkitsoq basin at the margin of the Inland Ice, central West Greenland. Rapp. Grønlands geol. Unders. 140.

\title{
Test drilling with a hot water jet at the Inland Ice margin, Pâkitsup, central West Greenland
}

\author{
Ole B. Olesen and Anders Clausen
}

A new hot water jet drill was tested on the Inland Ice margin north-east of Jakobshavn. A total of $2436 \mathrm{~m}$ was drilled and data on drilling performance is presented together with the preliminary interpretation of borehole logging.

\section{Introduction}

One of the main problems in assessing potential water sources for hydroelectric power plants using meltwater from the Inland Ice is the delineation of the drainage basin. In the case of the proposed project at Paakitsup Akuliarusersua this delineation has been attempted by a combination of surface topography and drainage systems, radio-echo soundings, mass balance measurements, ice dynamics and present theories on the internal drainage of glaciers (summarized by Thomsen et al., 1986).

The subglacial or englacial drainage of glaciers, particularly where temperatures are below the pressure melting point is not very well understood. From both practical and scientific considerations it therefore seemed reasonable for GGU to start research using the basin at Paakitsup Akuliarusersua as a test area. Among important aspects of this research are the monitoring of hydrostatic pressure variations within the drainage system, tracer experiments and subglacial and surface topographic mapping. This requires the installation of gauges at different levels in the ice, the injection of tracers and withdrawal of water from specified locations and spot checks on the accuracy of the radio-echo soundings made in the area. The only practical way of accomplishing this programme is by drilling, and it was therefore decided that GGU should either buy or develop its own drill.

\section{Equipment}

As no ice-core samples were required and a regular borehole diameter was unimportant, it was decided to use a hot water jet to penetrate the ice. This type of drilling is the fastest and most reliable method and has been widely used in the Alps (Iken et al., 1977). We had an opportunity to examine the Swiss system at the Swiss Federal Institute of Technology (ETH) in Zürich and used it as a basis for our own drill.

The basic principle consists of pumping water through a heating system and into a hose with a rigid drill tip with a nozzle. The hot water from the nozzle melts the ice in front of it and flows back up the drill hole. All the main elements in the system are commercially available, but the actual fitting and mounting of the different components is unique to this system. The central part of the drill consist of two units, a power unit and a heating unit (fig. 1). The power unit is a $6 \mathrm{~kW}$ four stroke gasoline engine with reduction gear connected with an $0.4 \mathrm{~kW} 220 \mathrm{~V}$ generator and a piston pump capable of delivering $18 \mathrm{l} / \mathrm{min}$. of water with a pressure of up to 100 bar. Fuel consumption is $2.5 \mathrm{l} / \mathrm{hr}$ and the total weight of this unit is $79 \mathrm{~kg}$. The heating unit is a water circulation coil with an oil burner (modified for using jet A1 fuel). The airblower and oil pump are driven by a flexible axle from the power unit, and current for the ignition is drawn from the generator. Fuel consumption is $11.6 \mathrm{l} / \mathrm{hr}$ corresponding to $113 \mathrm{~kW}$ and the weight is $127 \mathrm{~kg}$. During drilling the two units can be used separately (to 


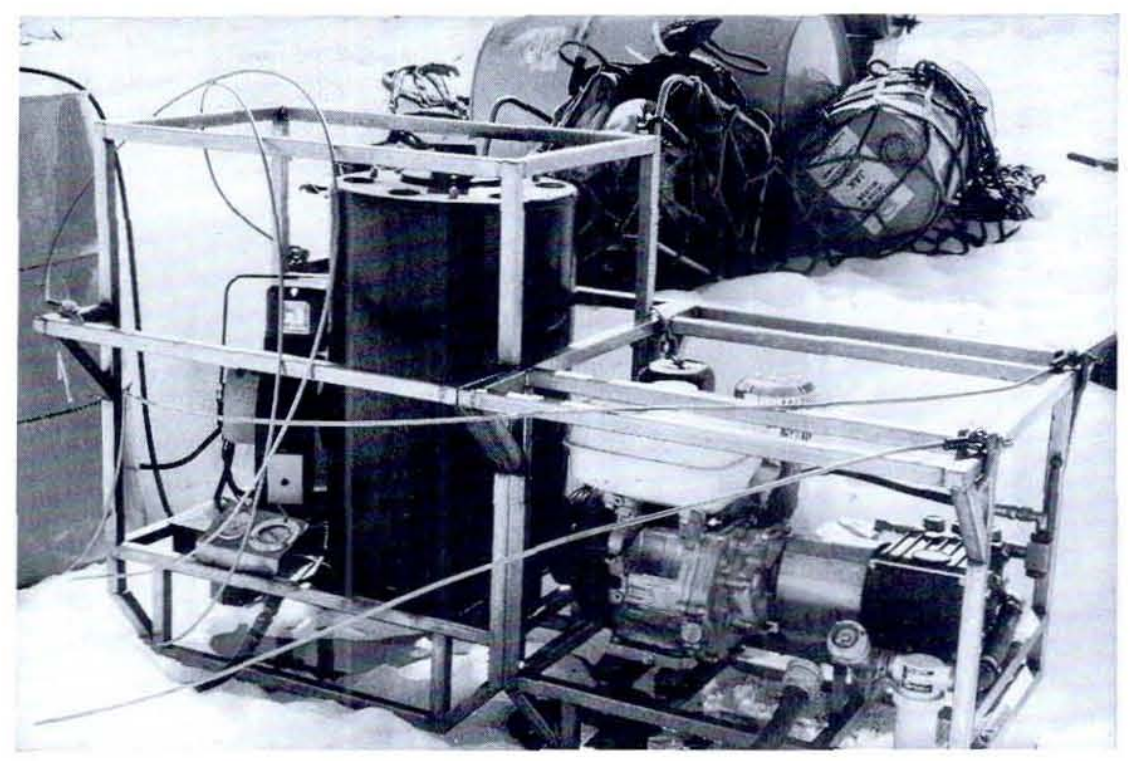

Fig. 1. Components of the drilling system. To the right, a gasoline engine and high pressure pump form the power unit. The heating unit is on the left. Units are bolted together for field operation.

the extent of the flexible axle) but will normally be bolted together to work as a single unit.

Further equipment used is $500 \mathrm{~m}$ of heat resistant high pressure hose (working temperature and pressure are $121^{\circ} \mathrm{C}$ and 138 bar) in lengths of $100 \mathrm{~m}$, a $2 \mathrm{~m}$ long 25 $\mathrm{mm}$ diameter stainless steel drill tip with interchangeable nozzles and a clinometer on top, a lightweight tripod with winch and pulley, and a low pressure pumping unit for use when water has to be drawn from farther away.

The total weight of the complete drilling system inclusive of tools and spare parts is $435 \mathrm{~kg}$.

\section{Field tests}

Before the actual deep drillings a few tests were made to determine the size of nozzle to be used. It was soon discovered that with the given weight of just under $5 \mathrm{~kg}$ for the drill tip, nozzles with an inner diameter of 2.4 $\mathrm{mm}$ or less forced the tube back up the drill hole. With a $2.5 \mathrm{~mm}$ nozzle it was impossible to steer the drill vertically, so in the end a $2.7 \mathrm{~mm}$ nozzle was chosen. This gives a pump pressure of 35 bar with one $100 \mathrm{~m}$ length of hose and all subsequent drillings were made with this nozzle,

Eight deep holes were made to depths between 270 and $383 \mathrm{~m}$ totalling $2,436 \mathrm{~m}$ (see Table 1 ). In two areas, two holes were drilled 10 to $15 \mathrm{~m}$ apart, while in the other areas only one hole was made (for site location, see map in Thomsen, 1988). Of the eight holes, five went to the bottom while two (nos $1 \mathrm{~A}$ and 6) are uncertain and one definitely stopped in the ice (no. 3A). The outlet temperature from the heating unit was just about $82^{\circ} \mathrm{C}$, giving a heating efficiency of above $90 \%$. To get an idea of the heat loss in the hose a thermistor was mounted in the drill tip and exposed to the circulating bore-hole water.

The measured temperatures are plotted in fig. 2 against length of hose between heater and thermistor housing. Typically about $20 \mathrm{~m}$ of hose was above the water-filled drill hole when temperatures were measured. As only a few data points are available a straight line has been fitted to the points. The data are, however, consistent with a heat loss of $2 \%$ per $10 \mathrm{~m}$ of hose which is very close to the $1.8 \%$ measured in an experiment in Copenhagen prior to the field tests.

In Table 1 measured drilling speeds in $\mathrm{m} / \mathrm{min}$, are

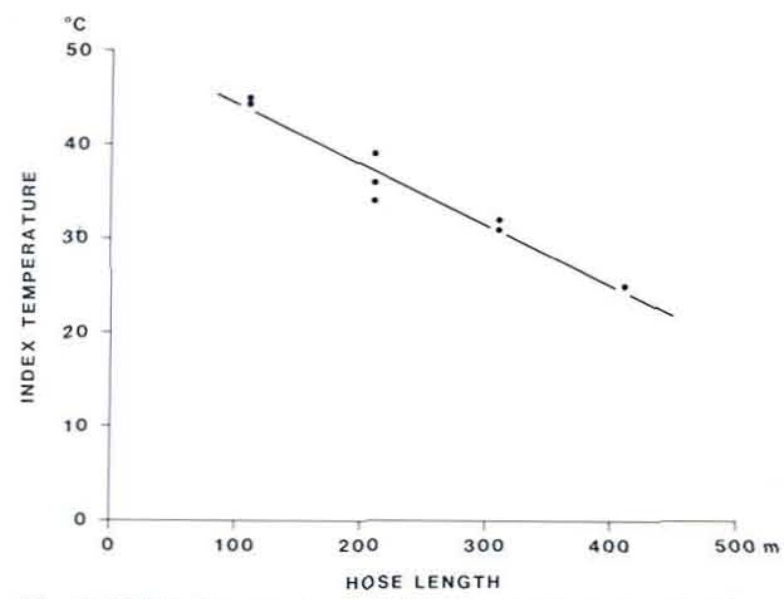

Fig. 2. Fall in temperature with increasing hose length. Temperatures are read with about $20 \mathrm{~m}$ of hose above the hole. For explanation of index temperature and thermistor setting see text. 
Table 1. Drilling speed and depth for hot water jet Paakitsup Akuliarusersua, Jakobshavn, West Greenland August 1987

Drilling speeds in metres per minute.

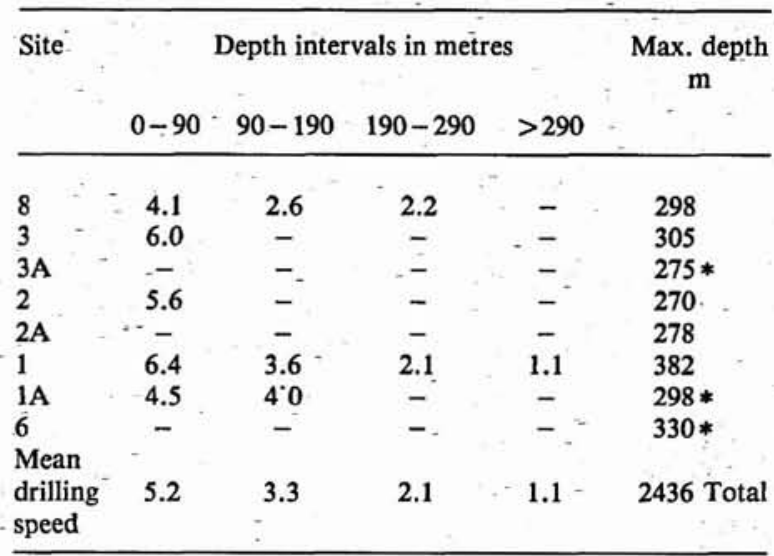

* Drilling did not reach bottom of glacier

listed for various intervals and the same figures are plotted in fig. 3. The actual measurements refer to times between fitting successive $100 \mathrm{~m}$ lengths of hose. No. corrections have been attempted to compensate for 'difficult' drilling conditions when the drill penetrated layers of ice with debris which had a considerable slowing effect.

All the listed drillings in Table 1 were carried out with the same nozzle which means that the pressure at the tip of the drill was constant. However, on one occasion a large nozzle $(3.0 \mathrm{~mm})$ was tried at a depth of $200 \mathrm{~m}$ and the drilling speed dropped to about one third of that with the $2.7 \mathrm{~mm}$ nozzle. Although this was the only trial it indicates that pressure has a very strong influence on drilling performance.

\section{Comments}

In general, drilling proceeded at an even speed but at sites 3 and $3 \mathrm{~A}$ a very resistant layer was encountered $220 \mathrm{~m}$ below the surface where drilling speed dropped to almost nil for 10 to $20 \mathrm{~m}$. Subsequent inspection of the nozzle showed distinct scratches along the sides but no fine particles were observed in the upwelling water in the drill hole. Most probably the layer encountered was a shear plane carrying material from the- bottom ùpstream of the drill site. Downstream from the site shear planes could be seen on the surface although these seemed to carry a relatively high content of fine particles of silt and clay sizes.

At site $1 \mathrm{~A}$ a deep layer carrȳing debris was encountered and a sample was unwittingly brought to the sur-

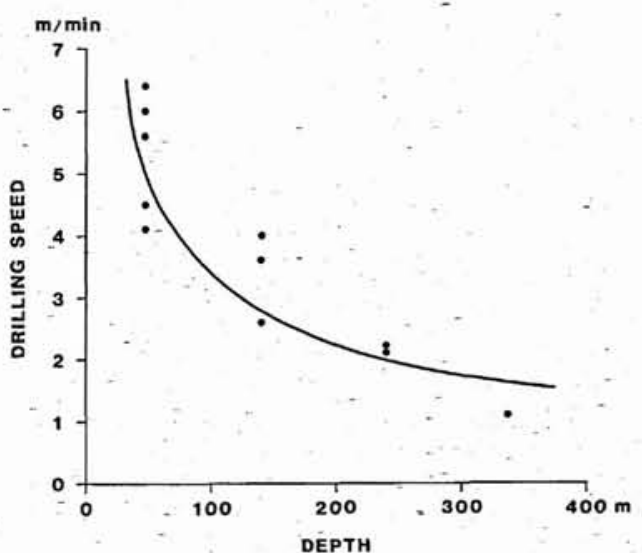

Fig. 3. Decrease of drilling speed with increasing depth. Same data as in Table 1.

face. In order to read the clinometer, water pressure was taken off the drill by suddenly turning the relief valve. The subsequent sudden pressure drop must have created a vacuum in the hose (probably due to the elastic stretching and contraction) and the nozzle became clogged with sand. The individual grains are up to $2.5 \mathrm{~mm}$ in diameter and are mostly sharp edged and hence have not been transported for long distances. The samples are being mineralogically examined for composition and possible provenance. The hole was not finished to the bottom because of refreezing in the hole while the nozzle was being changed and examined for damage.

At drill site 1 the drill seemed to hit a void at $180 \mathrm{~m}$ below the surface when the water level in the drill hole suddenly dropped. When the drilling stopped, the water level rose again and stood at $20 \mathrm{~m}$ below surface, that is when an additional $2.5 \mathrm{~m}^{3}$ of water had been pumped into the hole.

In Table 2 ice thickness measured by both radio-echo soundings (EMR) and by drilling with the hot water jet is compared. EMR thickness is read by interpolation between computer-generated contours based on a 100

Table 2. Comparison of ice thickness measured by radio-echo soundings (EMR) and hot-water jet drill holes

\begin{tabular}{lcccc}
\hline Site & Drilling & EMR & \multicolumn{2}{c}{ Difference } \\
& m & m & m & $\%$ \\
\hline 8 & 298 & 300 & 2 & 0.7 \\
3 & 305 & 300 & 5 & 1.7 \\
2 & 270 & 240 & 30 & 11.1 \\
$2 \mathrm{~A}$ & 278 & 240 & 38 & 13.7 \\
1 & 382 & 400 & 18 & 4.7 \\
\hline
\end{tabular}


$\mathrm{m}$ grid of filtered data. Sites 2 and $2 \mathrm{~A}$ are only $10 \mathrm{~m}$ apart and the difference of $11 \%$ and $14 \%$ in the two data sets are probably due to the great bottom gradient of approximately $40^{\circ}$ which both aggravates positioning errors and influences EMR interpretation.

Although the overall performance of the drilling system was very satisfactory, a few things must be changed to improve determination of when the bottom has been reached. For instance, the present clinometer is too sensitive to vibrations so that the pump has to be stopped during the 'feeling' for the bottom. A heavier drill tip should be used both for the advantage of drilling with a smaller diameter nozzle and for the bigger loss of weight when the tip rests on the bottom, making it easier for the drilling crew to detect when to stop paying out more hose.

\section{References}

Iken, A., Röthlisberger, H. \& Hutter, K. 1977: Deep drilling with a hot water jet. Z. Gletscherk. Glazialgeol. 12(2), 143156.

Thomsen, H. H. 1988: Mass balance, ice velocity and ice temperature at the Inland Ice margin north-east of Jakobshavn, central West Greenland. Rapp. Gronlands geol. Unders. 140 (this report).

Thomsen, H. H., Thorning, L. \& Braithwaite, R. J. 1986: Vurdering af de gletscher-hydrologiske forhold på Indlandsisen ved Paakitsup Akuliarusersua, Ilulissat/Jakobshavn. Arbejdsnotat. Grønlands geol. Unders., 42 pp.

A. C., Steen Andersen Aps., Tagensvej 147, 2400 Copenhagen $N V$, Denmark. 